\title{
Antimicrobial susceptibility profile of Streptococcus agalactiae strains isolated from bovine mastitis
}

\section{Perfil de susceptibilidade a antimicrobianos em Streptococcus agalactiae isolados de mastite bovina}

\author{
Geraldo Márcio da Costa $^{1}$ (D); Núbia Aparecida Ribeiro ${ }^{1}$; Maysa Serpa Gonçalves ${ }^{1}$; Juliana Rosa da Silva ${ }^{2}$; \\ Dirceia Aparecida da Costa Custódio'; Gláucia Frasnelli Mian ${ }^{1}$ \\ ${ }^{1}$ Universidade Federal de Lavras, Faculdade de Zootecnia e Medicina Veterinária, Lavras - MG, Brazil \\ ${ }^{2}$ Faculdade de Ciências e Tecnologias de Campos Gerais, Campos Gerais - MG, Brazil
}

\begin{abstract}
Bovine mastitis is the most important disease of dairy herds worldwide. Its main etiologic agents are bacteria, including Streptococcus agalactiae. The importance of this agent in bovine mastitis is because it is highly contagious and has a high impact on the occurrence of clinical mastitis cases and in the increase of the bulk milk somatic cell counts. The dry cow therapy and the treatment of the clinical mastitis cases stand out among the measures to control intramammary infections in cows. However, these strategies require knowledge about the antimicrobial susceptibility of the causal microorganisms. Thus, this study aimed to evaluate the antimicrobial susceptibility of 89 S. agalactiae strains isolated from bovine mastitis between the years 2004 and 2008 in dairy herds from Campo das Vertentes region, Minas Gerais State, Brazil. The disc diffusion technique was used and the antimicrobials currently used in mastitis therapy were tested. The isolates tested showed $100 \%$ susceptibility to chloramphenicol, ceftiofur, cefotaxime, enrofloxacin, and cefquinome. High frequencies of susceptibility ( $>95 \%)$ were also observed for the beta-lactams (penicillin G, ampicillin, and oxacillin), cephalosporins (cephalotin, ceftiofur, cefotaxime, cefoperazone, and cefquinome), florfenicol, gentamicin, lincomycin, nitrofurantoin, and sulfamethoprim. The strains showed high frequencies of resistance to neomycin (15.74\%), and tetracycline (21.35\%). Multidrug resistance was detected in $2.25 \%$ of the tested isolates. The results pointed to variations in the antimicrobial susceptibility profiles of the studied strains and the importance of the use of the susceptibility tests to determine the correct antimicrobial to be applied in the treatment of bovine mastitis caused by S. agalactiae. The high frequencies of resistance observed to some antimicrobials, such as neomycin and tetracycline, commonly used in the treatment of mastitis and other pathologies, highlighted the need for more judicious use of antimicrobials on dairy farms.
\end{abstract}

Keywords: Resistance. Intramammary infection. Multidrug resistance. Bovine diseases.

\section{RESUMO}

A mastite é a principal doença de bovinos leiteiros em todo o mundo e tem como principais agentes as bactérias, entre as quais Streptococcus agalactiae. Esse agente se destaca por ser altamente contagioso e pelos reflexos que causa na incidência de casos clínicos e no incremento da contagem de células somáticas do leite do tanque. Para o controle desta enfermidade, destacam-se a terapia de vacas secas e o tratamento de casos clínicos, medidas que requerem o conhecimento do perfil de sensibilidade dos agentes causais aos antimicrobianos. Este estudo teve como objetivo avaliar os perfis de suscetibilidade a antimicrobianos em 89 amostras de S. agalactiae isoladas de casos de mastite bovina em rebanhos da região de Campo das Vertentes, Minas Gerais, no período de 2004 a 2008. A técnica de difusão em discos foi utilizada e os antimicrobianos correntemente empregados na terapia da mastite foram testados. Os testes de suscetibilidade antimicrobiana apontaram 100\% de susceptibilidade para cloranfenicol, ceftiofur, cefotaxima, enrofloxacina e cefquimona. Níveis elevados de susceptibilidade ( $>95 \%)$ foram observados para os betalactâmicos, florfenicol, gentamicina, lincomicina, nitrofurantoína e sulfametoprim. Altas frequências de resistência foram observadas para neomicina $(15,74 \%)$ e tetraciclina $(21,35 \%)$. Dois isolados multirresistentes $(2,25 \%)$ foram encontrados. Os resultados apontaram variações nos perfis se suscetibilidade aos antimicrobianos na população analisada, indicando a importância do uso do antibiograma para a escolha mais criteriosa dos antibacterianos a serem utilizados para o tratamento da mastite bovina causada por S. agalactiae. As altas frequências de resistência detectadas para alguns dos 
antimicrobianos comumente utilizados para o tratamento de mastite e outras patologias, tais como a neomicina e a tetraciclina, salientam a necessidade de monitoramento permanente do perfil de suscetibilidade aos antimicrobianos e do uso mais criterioso dos mesmos nos rebanhos leiteiros.

Palavras-chave: Resistência. Infecção intramamária. Multirresistência. Doenças de bovinos.

\section{Correspondence to:}

Geraldo Márcio da Costa

Universidade Federal de Lavras, Faculdade de Zootecnia e

Medicina Veterinária

Campus Universitário Lavras, Caixa Postal 3037

CEP: 37200-000, Lavras - MG, Brazil

e-mail: gmcosta@ufla.br

Received: November 12, 2020

Approved: April 12, 2021

How to cite: Costa GM, Ribeiro NA, Gonçalves MS, Silva JR, Custódio DAC, Mian GF. Antimicrobial susceptibility profile of Streptococcus agalactiae strains isolated from bovine mastitis. Braz J Vet Res Anim Sci. 2021;58:e178109. https://doi.org/10.11606/issn.1678-4456.bjvras.2021.178109

\section{Introduction}

Streptococcus agalactiae belongs to Group B of Lancefield. It is commonly called GBS. It is a pathogen involved in several diseases in animals and human beings. In cattle, this agent detaches as one of the most frequent in the bovine intramammary infections (IMI) worldwide (Keefe et al., 2011; Radtke et al., 2012; Mesquita et al., 2019).

Bovine mastitis is one of the most frequent and economically relevant diseases affecting dairy herds on all continents. The high economic impact of this illness has been primarily attributed to the reduction of milk production, the discarded milk of animals undergoing treatment, changes in the milk composition, and the high costs of treatment of affected animals (Halasa et al., 2007). The losses in the milk industry occur mainly due to the alterations in the quality of the raw milk, as the mastitis causes a reduction in the contents of casein and fat milk and an increase in the bulk milk somatic cell count (BMSCC) (Costa, 2014; Santos \& Laranja, 2019).

Besides economic losses, bovine mastitis also causes public health concerns due to the presence in the milk and its derivatives of microorganisms with zoonotic potential, residual antibiotics, and the presence of resistant bacteria that can be propagated in the community (Pinto et al., 2014; Botelho et al., 2018).

The bacteria stand out among the agents involved in the etiology of bovine mastitis (Costa, 2014), and among these, S. agalactiae. This agent, in general, presents high infection rates in herds without adequate measures for the control and prevention of contagious mastitis (Duarte et al., 2004; Mesquita et al., 2019). Previous studies have indicated a high prevalence of bovine IMI caused by GBS in Brazilian herds. Elias et al. (2012) verified IMI prevalence of 39.7\% due to this agent in herds from Minas Gerais State, while Mesquita et al. (2019) reported that this agent was isolated among $67 \%$ of dairy farms from the Campo das Vertentes region in this same state. Studies carried out to examine the prevalence of GBS in South American dairy herds pointed out that this bacterium was present in $60 \%$ of herds in Brazil (Duarte et al., 2004), 42\% in Colombia (Keefe et al., 2011), and 11\% in Uruguay (Gianneechini et al., 2002). In addition, it has been considered as a re-emergent mastitis pathogen in dairy herds in Europe (Radtke et al., 2012).

Antimicrobials have been increasingly used in dairy cattle, due to intensive management practices and mainly to mastitis treatment. In cattle mastitis, blitz therapy is recommended as a control and eradication measure in herds infected by $S$. agalactiae. However, the intensive use of antimicrobial agents has contributed to an increase of resistance levels of the mastitis pathogens (Mota et al., 2005; White \& McDermott, 2001).

According to Machado et al. (2008), different species of multidrug-resistant bacteria have been isolated from bovine IMI, limiting the therapeutic options for animals affected by mastitis. The phenomenon of resistance is a dynamic process that presents temporal and spatial variations, which justify the execution of this study. Besides, studies about the resistance of $S$. agalactiae involved in bovine IMI are scarce about the other "major pathogens" of mastitis.

Thus, in the present study, the antimicrobial susceptibility profile of S. agalactiae strains, isolated from mastitis cases of dairy herds located in the region of Campo das Vertentes, Minas Gerais State, Brazil, was evaluated concerning antimicrobials routinely used for the treatment of bovine mastitis. The threats to human health related to antimicrobial resistance in GBS are also discussed.

\section{Material and Methods}

In this study, 89 strains of $S$. agalactiae isolated from milk samples sent to the Laboratory of Microbiology of the Department of Veterinary Medicine from the Federal University of Lavras were submitted to antimicrobial tests. 
The milk samples were collected from cows affected by clinical or subclinical mastitis, from 21 dairy herds located in the Campo das Vertentes region of the Minas Gerais State, between 2004 and 2008. The strains were isolated and then identified according to the National Mastitis Council (National Mastitis Council, 2004). After phenotypic characterization of the strains, antimicrobial susceptibility tests were performed through disk diffusion according to the Clinical Laboratory Standards Institute (Clinical and Laboratory Standards Institute, 2018). The following antimicrobials groups were tested: penicillin (penicillin G, ampicillin, and oxacillin), amphenicols (chloramphenicol and florfenicol), cephalosporins (cephalotin, ceftiofur, cefotaxime, cefoperazone, and cefquinome), quinolones (enrofloxacin), aminoglycosides (gentamicin and neomycin), lincosamides (lincomycin), tetracycline, sulfonamides + trimethoprim (sulfamethoprim) and nitrofurans (nitrofurantoin).

The reading and interpretation of the susceptibility test results were performed according to the CLSI standards (Clinical and Laboratory Standards Institute, 2018). The resistance rates were measured for each antibiotic. Moderately susceptible isolates were considered resistant to obtain total resistance rates. The strain was considered multidrug-resistant when showed resistance to three or more antimicrobial groups, according to Magiorakos et al. (2011). The strains Staphylococcus aureus ATCC 25923, Escherichia coli ATCC 25922, and Pseudomonas aeruginosa ATCC 27853 were used as controls of the susceptibility tests.

\section{Results}

The results of susceptibility tests are shown in Table 1 . All strains tested were susceptible to chloramphenicol, ceftiofur, cefotaxime, enrofloxacin, and cefquinome. High frequencies of susceptibility ( $>95 \%$ ) were observed for all of the beta-lactams tested, and also for florfenicol, gentamicin, lincomycin, nitrofurantoin, and sulphamethoprim. Meanwhile, high frequencies of resistance were observed for neomycin (15.74\%) and tetracycline (21.35\%).

According to resistance among antimicrobial groups, 13 resistance profiles were observed (Figure 1) and two strains (2.25\%) showed multidrug resistance (Figure 2).

\section{Discussion}

IMI caused by $S$. agalactiae are generally associated with the increase of BMSCC, the increase of clinical mastitis cases and bacterial counts in bulk milk, and milk losses in infected herds (Keefe, 2012; Merl et al., 2003). This bacterium also has high importance in aquaculture, accounting for high morbidity and mortality in cases of septicemia and meningoencephalitis in freshwater, marine, and estuarine fish (Evans et al., 2008; Mian et al., 2009). In human beings, this microorganism has been associated with systemic infections, pneumonia, and meningitis in neonates and immunocompromised adults (Johri et al., 2006; Pinto et al., 2014). The great importance of S. agalactiae in human and animal health requires the continuous monitoring of the resistance profiles of this pathogen, considering the risks of inter-species infections and the horizontal transmission of resistance genes among strains isolated from the same or different hosts (Dogan et al., 2005; Pinto et al., 2014).

S. agalactiae is one of the most important pathogens associated with bovine mastitis in Brazil (Cunha et al., 2016; Elias et al., 2012; Mesquita et al., 2019; Oliveira et al., 2013). However, studies about the antimicrobial susceptibility profiles of this pathogen isolated from IIM are scarce in Brazil and worldwide. In general, when one discusses the treatment of mastitis caused by this agent, the common empirical affirmation is that this pathogen is very susceptible to antimicrobials and that the treatment of IMI caused by it is not a problem, compared to other mastitis pathogens (Staphylococcus aureus, for example). However, previous studies have demonstrated significant resistance to antimicrobials among the GBS strains, as well temporal and spatial variations in susceptibility profiles between isolates from different herds and regions (Duarte et al., 2004; Oliveira et al., 2011; Silva et al., 2017). According to Guérin-Faublée et al. (2002), there are difficulties in

Table 1 - Frequency of resistance in 89 Streptococcus agalactiae strains isolated from bovine mastitis in dairy herds from the Campo das Vertentes region, Minas Gerais State, Brazil, 2004-2008

\begin{tabular}{lcc}
\hline \multirow{2}{*}{ Antimicrobials } & \multicolumn{2}{c}{ Resistant isolates } \\
\cline { 2 - 3 } & Frequency & Percentage \\
\hline Ampicillin & $4 / 89$ & 4.5 \\
Oxacillin & $4 / 89$ & 4.5 \\
Penicillin $^{1}$ & $4 / 86$ & 4.66 \\
Cloramphenicol $^{\prime}$ & $0 / 89$ & 0 \\
Florphenicol $^{2}$ & $1 / 74$ & 1.36 \\
Cephalotin $^{\prime}$ & $1 / 89$ & 1.13 \\
Ceftiofur $_{\text {Cefotaxime }}$ & $0 / 89$ & 0 \\
Cefoperazone & $0 / 89$ & 0 \\
Cefquinome & $1 / 89$ & 1.13 \\
Enrofloxacin & $0 / 89$ & 0 \\
Gentamicin & $0 / 89$ & 0 \\
Neomycin & $3 / 89$ & 3.38 \\
Lincomycin & $14 / 89$ & 15.74 \\
Nitrofurantoin & $7 / 89$ & 7.87 \\
Tetracycline & $2 / 89$ & 2.25 \\
Sulphamethoprim & $19 / 89$ & 21.35 \\
\hline
\end{tabular}

1-Only 86 strains were tested to penicillin. 2- Only 74 strains were tested to florphenicol. 


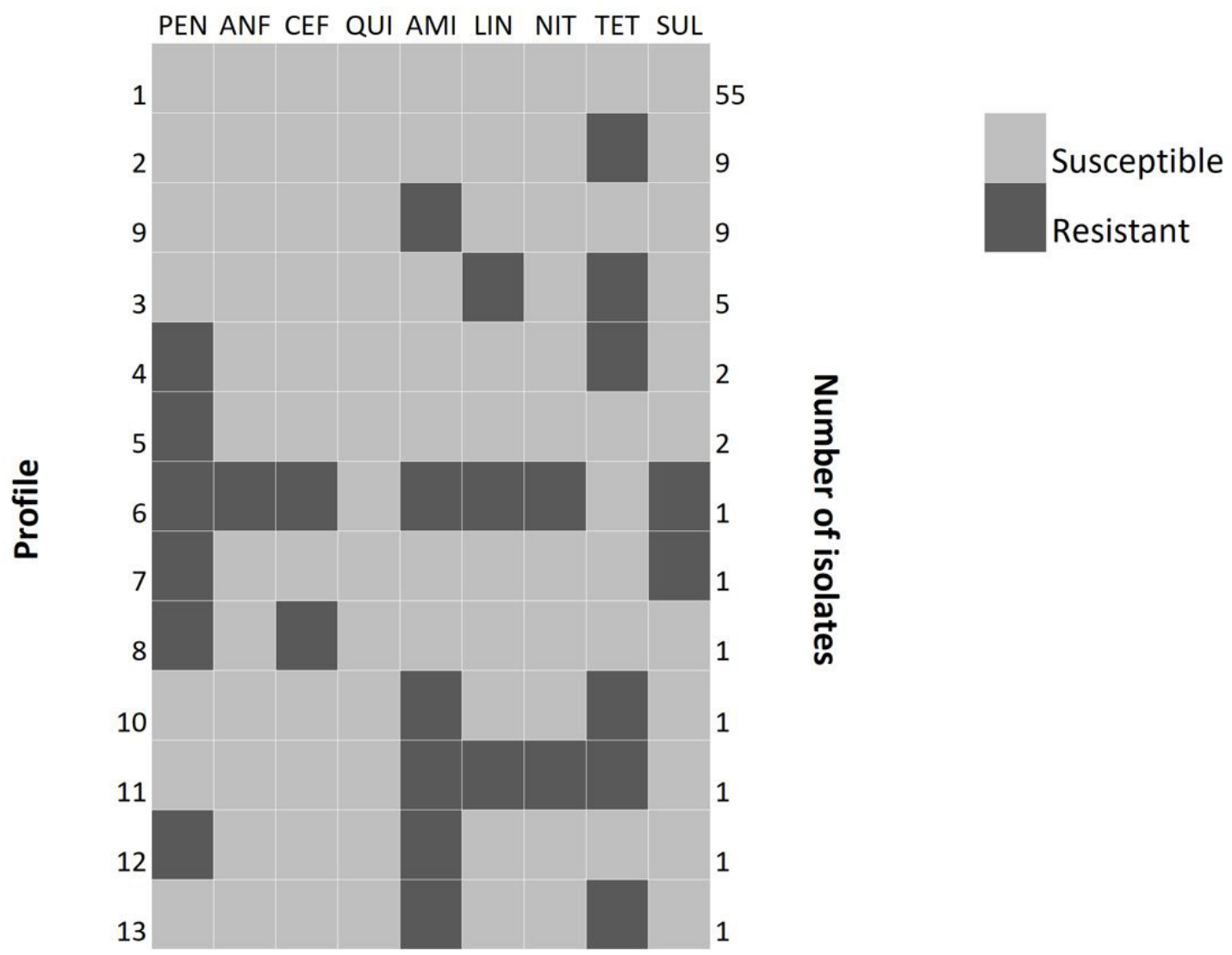

Figure 1 - Resistance profiles of 89 de Streptococcus agalactiae strains isolated from bovine mastitis in dairy herds from the Campo das Vertentes region, Minas Gerais State, Brazil, 2004-2008. PEN= Penicillins; ANF= Amphenicols; $\mathrm{CEF}=$ Cephalosporins; QUI=Quinolones; AMI: Aminoglycosides; LIN= Lincosamides; NIT= Nitrofurantoin; TET= Tetracycline; $\mathrm{SUL}=$ Sulphamethoprim.

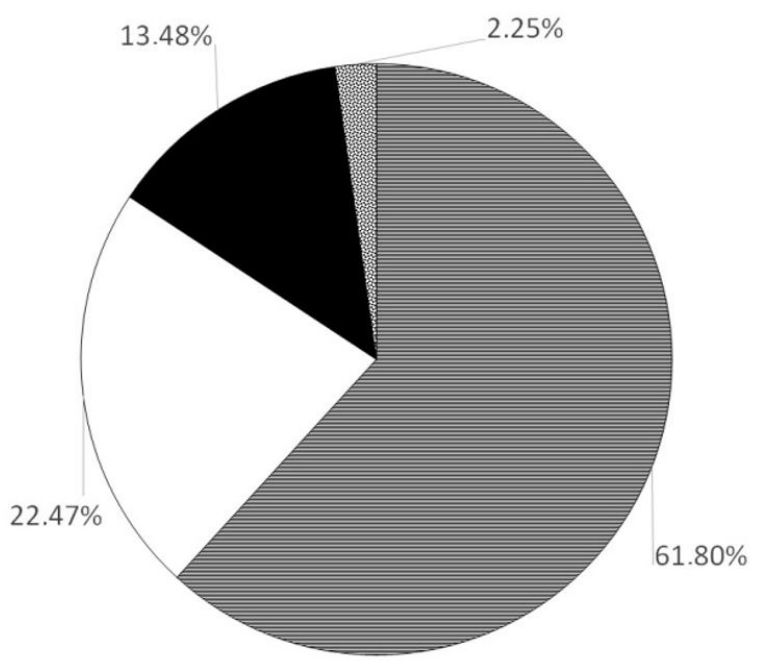

目 Susceptible to all groups

\author{
$\square$ Resistant to one \\ antimicrobial group
}

Resistant to two antimicrobial groups

圈 Multidrug resistant

Figure 2 - Frequencies of non-resistant, resistant to one or two antimicrobials, and multidrug-resistant strains among 89 Streptococcus agalactiae strains isolated from bovine mastitis in dairy herds from the Campo das Vertentes region, Minas Gerais State, Brazil. 2004-2008.

comparing results from different studies because of variations in the number of isolates, drugs tested, and methodologies employed.

Besides the high importance of GBS as an animal pathogen, involved in several pathologies in different hosts, S. agalactiae also has high importance in public health. High resistance levels have been demonstrated in strains isolated from human beings (Botelho et al., 2018; Jaramillo-Jaramillo et al., 2018).

The indiscriminate use of antimicrobials in animal production strongly contributes to antimicrobial resistance in bacteria. We detected resistance to antimicrobials routinely 
used in the treatment of bovine mastitis in Brazilian dairy herds, like neomycin (15.74\%) and tetracycline (21.35\%). Similar indexes of resistance to tetracycline and neomycin were demonstrated in other studies performed with GBS and Streptococcus spp. isolated from bovine mastitis (Alekish et al., 2013; Duarte et al., 2004; Guérin-Faublée et al., 2002; Idriss et al., 2014; Rato et al., 2013; Silva et al., 2017).

The tetracycline genetic resistance determinants in Streptococcus are constituted principally by six resistance genes $($ tet $\mathrm{K}$, tet $\mathrm{L}$, tet $\mathrm{M}$, tet $\mathrm{O}$, tet $\mathrm{Q}$, and tet $\mathrm{T})$ characterized by two action mechanisms: the genes coding for efflux proteins and those coding for ribosomal protection enzymes (Haenni et al., 2018). These resistance genes have been described in GBS isolated from bovine mastitis (Gao et al., 2012; Silva et al., 2017). Although these genes were not evaluated in the present work, its hypothetical presence associated with the intense use of this class of antimicrobial in dairy farms from Brazil may explain the resistance levels to tetracycline observed in our study.

Among the tested aminoglycosides, the indexes of susceptibility to neomycin and gentamicin were very discrepant. Although used in the composition of medicines to treat mastitis in cows in Brazil, neomycin is not commonly tested in studies performed with S. agalactiae isolated from mastitis cases. However, the results observed in the present study highlight the alarming levels of resistance to this antibiotic among the studied strains.

Resistance to gentamicin is a hallmark of GBS worldwide. Indeed, studies performed in China, Portugal, and Brazil showed respectively $29.4 \%, 80.6 \%$, and $100 \%$ of resistance to gentamicin in Streptococcus spp. and specifically in $S$. agalactiae (Duarte et al., 2004; Gao et al., 2012; Rato et al., 2013). In contrast, our findings demonstrated $96.62 \%$ of susceptibility of the strains to gentamicin. Paradoxically, gentamicin is one of the most common antimicrobials used for mastitis treatment in dairy herds in the region of origin of the isolates. Our findings corroborate with another work conducted by Silva et al. (2017), which demonstrated the susceptibility of $90.7 \%$ to gentamicin among strains of S. agalactiae isolated from different states of Brazil. Besides gentamicin, we also found high susceptibility of the isolate to beta-lactams. High susceptibility to this class of antimicrobials was also observed in several studies among S. agalactiae strains isolated from bovine mastitis (Kaczorek et al., 2017; Minst et al., 2012; Silva et al., 2017), demonstrating that this group of antimicrobials may be the first choice for the treatment of IMI caused by this pathogen.

According to Myllys et al. (1994), bacterial resistance to antimicrobials is a very dynamic phenomenon, which is closely related to changes in management, such as the systematic use of antimicrobials, animal husbandry, and the use of mechanical milking. This phenomenon leads to increased difficulties for the elimination of IMI and it facilitates the dissemination of resistant bacterial clones in the dairy farms. The adequate treatment of clinical cases and dry cow therapy are essential tools for the control and prevention of bovine mastitis (Costa, 2014). But the success of these measures depends on the correct choice and dose of the drugs used, the diffusion of the drugs in the mammary gland, the physiological status of the animal at the time of treatment, and the kind of pathogen involved (Erskine et al., 2003; Gruet et al., 2001). For an effective mastitis control program, it is of great importance to identify the involved pathogen and trace its resistance profile to antimicrobials, as it can be extremely variable between microorganisms of the same species and even within the same herd (Costa, 2014; McKeller, 1991).

Several medicines intensively used in the treatment of pathologies caused by GBS in animals, mainly in mastitis, are also used in the treatment of human diseases. The high pressure of selection caused by the intensive and sometimes abusive use of antimicrobials contributes to the increase of antimicrobial resistance. This creates the risk of the inefficacy of the treatment protocols for animal and human infections caused by this pathogen. Futhermore, the occurrence of multidrug resistance (MDR) strains of GBS among animals, especially in fish and cattle, increases the threats to human health by the occurrence of interspecies infection, as pointed out in several studies (Botelho et al., 2018; Jaramillo-Jaramillo et al., 2018), and the risk of horizontal transference of resistance genes among GBS of animal and human sources (Pinto et al., 2014). In our study, we found two MDR strains, one of which is resistant to seven classes of antimicrobials, which highlights the need for surveillance over the emergence of MDR S. agalactiae among animal strains.

Bovine IMI represents a threat to human health not only by alterations in milk composition and the involvement of zoonotic pathogens in its etiology. In mastitis cases, there is a risk of transmission of resistant strains from animals to humans by the occupational activities in infected herds and by the consumption of contaminated dairy foods, especially raw milk and its unpasteurized derivatives, as was shown by Jaramillo-Jaramillo et al. (2018). These authors evaluated the transmission of GBS between cattle and people on 33 dairy farms in Colombia and compared the antimicrobial resistance profiles of isolates from both host species. A total of 60 human strains of GBS isolated 
from the throat and rectal swabs from 191 people and 301 strains isolated from rectal swabs and milk samples from cattle were compared by MLST. The sequence type 1 was the most common among the strains in both host species and two members of the bovine-specific clonal complex 61/67 were isolated from human samples, demonstrating the risk of interspecies infections. Also, in this study, a high prevalence of penicillin resistance was observed among strains of both sources. This shows how dynamic the phenomenon of resistance among the mastitis pathogens is and the need for its permanent surveillance as discussed above. The risk of transmission of GBS by the consumption of milk and its derivatives is less studied, although the GBS transmission by the consumption of raw fish was shown in Singapore (Kalimuddin et al., 2017).

Besides the threat of interspecies transmission, there is also the likelihood of horizontal transference of resistant genes from GBS of bovine origin to GBS from human source by mobile genetic elements as shown by Pinto et al. (2014). These authors evaluated the presence of $t e t M$ and tet $O$ resistance genes and conjugative transposons conferring resistance to erythromycin among $S$. agalactiae strains isolated from human and bovine sources and the ability for transferring resistance determinants between strains from both origins. They showed the conjugative transfer of erm $A, \operatorname{ermB}$, mef, tet $M$, and tet $O$ resistance genes from bovine donor strain to human recipient strain.

The use of antimicrobials is indispensable to protect human and animal health as animal welfare. However, the incorrect use of medicines worldwide has contributed to the increase of the resistance of pathogens involved in human and animal diseases. This poses a threat to controlling bacterial diseases in humans and animals throughout the world (World Organization for Animal Health, 2021). It is important to emphasize that, according to the World Health Organization (WHO), resistance is currently one of the greatest public health problems worldwide, putting at risk mainly immunodeficient individuals, such as neonates, pregnant women, and the elderly. As such, resistance requires the WHO's permanent monitoring, as well as the dissemination of its knowledge and implications for the collective health.

\section{Conclusions}

Most of the strains showed high susceptibility to the tested antimicrobials, except to tetracycline and neomycin. The phenomenon of multidrug resistance was observed in $2.25 \%$ of strains. Our results highlight the importance of the use of the susceptibility tests to define the therapeutic protocols for mastitis control, to monitor the resistance profiles of $S$. agalactiae, and promote the more judicious use of antimicrobials in dairy farms to avoid the increase of resistance and its negative impact in the animal and human health.

\section{Conflict of Interest}

The authors declare that they have no conflict of interest.

\section{Ethics Statement}

The authors declare no direct animal use in the experiment.

\section{References}

Alekish MO, Al-Qudah KM, Al-Saleh A. Prevalence of antimicrobial resistance among bacterial pathogens isolated from bovine mastitis in northern Jordan. Rev Med Vet (Toulouse). 2013;164(6):319-26.

Botelho ACN, Ferreira AFM, Fracalanzza SEL, Teixeira LM, Pinto TCA. A perspective on the potential zoonotic role of Streptococcus agalactiae: searching for a missing link in alternative transmission routes. Front Microbiol. 2018;9(MAR):1-5. http://dx.doi.org/10.3389/fmicb.2018.00608. PMid:29643850.

Clinical and Laboratory Standards Institute. VET08 Performance standards for antimicrobial disk and dilution susceptibility tests for bacteria isolated from animals. 5th ed. Wayne: CLSI; 2018. 156 p.
Costa GM. Mastite Bovina. In: Silva JCPM, Oliveira AS, Veloso CM. Manejo e administração em bovinocultura leiteira. 2nd ed. Viçosa: Produção Independente; 2014. 596 p.

Cunha AF, Bragança LJ, Quintão LC, Coelho KS, De Souza FN, Pinho Cerqueira MMO. Prevalence, etiology and risk factors of clinical mastitis in dairy cattle of Viçosa-MG. Acta Vet Bras. 2016;10(1):48-54. http://dx.doi.org/10.21708/ avb.2016.10.1.5476.

Dogan B, Schukken YH, Santisteban C, Boor KJ. Distribution of serotypes and antimicrobial resistance genes among Streptococcus agalactiae isolates from bovine and human hosts. J Clin Microbiol. 2005;43(12):5899-906. http://dx.doi.org/10.1128/JCM.43.12.5899-5906.2005. PMid:16333073. 
Duarte RS, Miranda OP, Bellei BC, Brito MAVP, Teixeira LM. Phenotypic and molecular characteristics of Streptococcus agalactiae isolates recovered from milk of dairy cows in Brazil. J Clin Microbiol. 2004;42(9):4214-22. http://dx.doi. org/10.1128/JCM.42.9.4214-4222.2004. PMid:15365014.

Elias AO, Cortez A, Brandão PE, da Silva RC, Langoni H. Molecular detection of Streptococcus agalactiae in bovine raw milk samples obtained directly from bulk tanks. Res Vet Sci. 2012;93(1):34-8. http://dx.doi.org/10.1016/j.rvsc.2011.07.016. PMid:21862092.

Erskine RJ, Wagner S, DeGraves FJ. Mastitis therapy and pharmacology. Vet Clin North Am Food Anim Pract. 2003;19(1):109-38, vi. http://dx.doi.org/10.1016/S07490720(02)00067-1. PMid:12682938.

Evans JJ, Bohnsack JF, Klesius PH, Whiting AA, Garcia JC, Shoemaker CA, Takahashi S. Phylogenetic relationships among Streptococcus agalactiae isolated from piscine, dolphin, bovine and human sources: A dolphin and piscine lineage associated with a fish epidemic in Kuwait is also associated with human neonatal infections in Japan. J Med Microbiol. 2008;57(11):1369-76. http://dx.doi.org/10.1099/jmm.0.478150. PMid:18927414.

Gao J, Yu FQ, Luo LP, He JZ, Hou RG, Zhang HQ, Li SM, Su JL, Han B. Antibiotic resistance of Streptococcus agalactiae from cows with mastitis. Vet J. 2012;194(3):423-4. http:// dx.doi.org/10.1016/j.tvjl.2012.04.020. PMid:22627045.

Gianneechini R, Concha C, Rivero R, Delucci I, Moreno López J. Occurrence of clinical and sub-clinical mastitis in dairy herds in the west littoral region in Uruguay. Acta Vet Scand. 2002;43(4):221-30. http://dx.doi.org/10.1186/17510147-43-221. PMid:12831175.

Gruet P, Maincent P, Berthelot X, Kaltsatos V. Bovine mastitis and intramammary drug delivery: review and perspectives. Adv Drug Deliv Rev. 2001;50(3):245-59. http://dx.doi. org/10.1016/S0169-409X(01)00160-0. PMid:11500230.

Guérin-Faublée V, Tardy F, Bouveron C, Carret G. Antimicrobial susceptibility of Streptococcus species isolated from clinical mastitis in dairy cows. Int J Antimicrob Agents. 2002;19(3):21926. http://dx.doi.org/10.1016/S0924-8579(01)00485-X. PMid:11932145.

Haenni M, Lupo A, Madec J-Y. Antimicrobial Resistance in Streptococcus spp. In: Stefan Schwarz, Lina Maria Cavaco, Jianzhong Shen. Antimicrobial Resistance in Bacteria from Livestock and Companion Animals. Wiley; 2018. p. 159-84.

Halasa T, Huijps K, Østerås O, Hogeveen H. Economic effects of bovine mastitis and mastitis management: A review. Vet
Q. 2007;29(1):18-31. http://dx.doi.org/10.1080/01652176.2 007.9695224. PMid:17471788.

Idriss SE, Foltys V, Tancin V, Kirchnerova K, Tancinova D, Zaujec K. Mastitis pathogens and their resistance against antimicrobial agents in dairy cows in Nitra, Slovakia. Slovak J Anim Sci. 2014;47(1):33-8.

Jaramillo-Jaramillo AS, Cobo-Ángel CG, Moreno-Tolosa Y, Ceballos-Márquez A. Antimicrobial resistance of Streptococcus agalactiae of human and bovine origin. Med. Vet. y Zootec. 2018;13(1):62-79. http://dx.doi.org/10.21615/cesmvz.13.1.5.

Johri AK, Paoletti LC, Glaser P, Dua M, Sharma PK, Grandi G, Rappuoli R, Group B. Streptococcus: global incidence and vaccine development. Nat Rev Microbiol. 2006;4(12):932-42. http://dx.doi.org/10.1038/nrmicro1552. PMid:17088932.

Kaczorek E, Małaczewska J, Wójcik R, Rękawek W, Siwicki AK. Phenotypic and genotypic antimicrobial susceptibility pattern of Streptococcus spp. isolated from cases of clinical mastitis in dairy cattle in Poland. J Dairy Sci. 2017;100(8):6442-53. http://dx.doi.org/10.3168/jds.2017-12660. PMid:28601447.

Kalimuddin S, Chen SL, Lim CTK, Koh TH, Tan TY, Kam M, Wong CW, Mehershahi KS, Chau ML, Ng LC, Tang WY, Badaruddin H, Teo J, Apisarnthanarak A, Suwantarat N, Ip M, Holden MTG, Hsu LY, Barkham T. Epidemic of Severe Streptococcus agalactiae Sequence Type 283 Infections in Singapore associated with the consumption of raw freshwater fish: a detailed analysis of clinical, epidemiological, and bacterial sequencing data. Clin Infect Dis. 2017;64(Suppl. 2):S145-52. http://dx.doi.org/10.1093/cid/cix021. PMid:28475781.

Keefe G. Update on control of staphylococcus aureus and Streptococcus agalactiae for management of mastitis. Vet Clin North Am Food Anim Pract. 2012;28(2):203-16. http:// dx.doi.org/10.1016/j.cvfa.2012.03.010. PMid:22664203.

Keefe GP, Chaffer M, Ceballos-Marquez A, Londoño M, Jaramillo M, Toro M. Effects of Streptococcus agalactiae on the Colombian dairy industry. Albuquerque, New Mexico: American Association of Bovine Practitioners; 2011.

Machado TRO, Correa MG, Marin JM. Antimicrobial susceptibility of coagulase-negative Staphylococci isolated from mastitic cattle in Brazil. Arq Bras Med Vet Zootec. 2008;60(1):278-82. http://dx.doi.org/10.1590/S010209352008000100041 .

Magiorakos AP, Srinivasan A, Carey RB, Carmeli Y, Falagas ME, Giske CG, Harbarth S, Hindler JF, Kahlmeter G, OlssonLiljequist B, Paterson DL, Rice LB, Stelling J, Struelens MJ, Vatopoulos A, Weber JT, Monnet DL. Multidrug-resistant, extensively drug-resistant and pandrug-resistant bacteria: an 
international expert proposal for interim standard definitions for acquired resistance. Clin Microbiol Infect. 2011;18(3):26881. http://dx.doi.org/10.1111/j.1469-0691.2011.03570.x. PMid:21793988.

McKeller QA. Intramammary treatment of mastitis in cows. In Pract. 1991;13(6):244-50. http://dx.doi.org/10.1136/ inpract.13.6.244.

Merl K, Abdulmawjood A, Lämmler C, Zschöck M. Determination of epidemiological relationships of Streptococcus agalactiae isolated from bovine mastitis. FEMS Microbiol Lett. 2003;226(1):87-92. http://dx.doi.org/10.1016/S03781097(03)00564-0. PMid:13129612.

Mesquita AA, Rocha CMBM, Bruhn FRP, Custódio DAC, Braz MS, Pinto SM, Silva DB, Costa GM. Staphylococcus aureus and Streptococcus agalactiae: Prevalence, resistance to antimicrobials, and their relationship with the milk quality of dairy cattle herds in minas gerais state, Brazil. Pesq Vet Bras. 2019;39(5):308-16. http://dx.doi.org/10.1590/16785150-pvb-5821.

Mian GF, Godoy DT, Leal CAG, Yuhara TY, Costa GM, Figueiredo HCP. Aspects of the natural history and virulence of Streptococcus agalactiae infection in Nile tilapia. Vet Microbiol. 2009;136(1-2):180-3. http://dx.doi.org/10.1016/j. vetmic.2008.10.016. PMid:19042097.

Minst K, Märtlbauer E, Miller T, Meyer C. Short communication: Streptococcus species isolated from mastitis milk samples in Germany and their resistance to antimicrobial agents. J Dairy Sci. 2012;95(12):6957-62. http://dx.doi.org/10.3168/ jds.2012-5852. PMid:22999286.

Mota RA, da Silva KPC, de Freitas MFL, Porto WJN, da Silva LBG. Utilização indiscriminada de antimicrobianos e sua contribuição a multirresitência bacteriana. Braz J Vet Res Anim Sci. 2005;42(6):465. http://dx.doi.org/10.11606/ issn.1678-4456.bjvras.2005.26406.

Myllys V, Honkanenbuzalski T, Huovinen P, Sandholm M, Nurmi E. Association of changes in the bacterial ecology of bovine mastitis with changes in the use of milking machines and antibacterial drugs. Acta Vet Scand. 1994;35(4):363-9. http://dx.doi.org/10.1186/BF03548309. PMid:7676918.

National Mastitis Council. Microbiological procedures for diagnosis of bovine udder infection and determination of milk quality. 4th ed. Madison: NMC; 2004. 47 p.

Oliveira CMC, Sousa MGS, Silva NS, Mendonça CL, Silveira JAS, Oaigen RP, Andrade SJT, Barbosa JD. Prevalência e etiologia da mastite bovina na bacia leiteira de Rondon do Pará, estado do Pará. Pesq Vet Bras. 2011;31(2):104-10. http:// dx.doi.org/10.1590/S0100-736X2011000200002.
Oliveira EF, Brito MAV, Lange CC, Mendonca LC, Meurer I. Prevalencia de patogenos contagiosos em rebanhos da associacao dos criadores de gado holandes do estado de Minas Gerais. Vet Zootec. 2013;20(1):265-8.

Pinto TCA, Costa NS, Corrêa ABA, de Oliveira ICM, de Mattos MC, Rosado AS, Benchetrit LC. Conjugative transfer of resistance determinants among human and bovine Streptococcus agalactiae. Braz J Microbiol. 2014;45(3):7859. http://dx.doi.org/10.1590/S1517-83822014000300004. PMid:25477908.

Radtke A, Bruheim T, Afset JE, Bergh K. Multiple-locus variant-repeat assay (MLVA) is a useful tool for molecular epidemiologic analysis of Streptococcus agalactiae strains causing bovine mastitis. Vet Microbiol. 2012;157(3-4):398404. http://dx.doi.org/10.1016/j.vetmic.2011.12.034. PMid:22266162.

Rato MG, Bexiga R, Florindo C, Cavaco LM, Vilela CL, Santos-Sanches I. Antimicrobial resistance and molecular epidemiology of streptococci from bovine mastitis. Vet Microbiol.2013;161(3-4):286-94. http://dx.doi.org/10.1016/j. vetmic.2012.07.043. PMid:22964008.

Santos MV, Laranja LF. Controle da mastite e qualidade do leite - Desafios e Soluções. Pirassununga, SP: Edição dos autores; 2019. $301 \mathrm{p}$.

Silva JR, Castro GDADC, Gonçalves MS, Custódio DADC, Mian GF, Costa GM. In vitro antimicrobial susceptibility and genetic resistance determinants of Streptococcus agalactiae isolated from mastitic cows in Brazilian dairy herds. Semin Agrar. 2017;38(4):2581-94. http://dx.doi.org/10.5433/16790359.2017v38n4SUPLp2581.

White DG, McDermott PF. Emergence and transfer of antibacterial resistance. J Dairy Sci. 2001;84:E151-5. http:// dx.doi.org/10.3168/jds.S0022-0302(01)70209-3.

World Organization for Animal Health [Internet]. Antimicrobial resistance. Paris, France: OIE; 2021 [cited $2021 \mathrm{Feb} 28$ ]. Available from: https://www.oie.int/en/ for-the-media/amr/.

Financial Support: This study was supported by Coordination for the Improvement of Higher Education Personnel-Brazil (CAPES) (Finance Code 001), Minas Gerais Research Support Foundation (Fapemig), and National Council for Scientific and Technological Development (CNPq). MS and DACC thank CAPES for their fellowship and NAR thanks CNPq for her fellowship. 